\title{
HISTORIA IMIGRACJI CHIŃCZYKÓW DO STANÓW ZJEDNOCZONYCH - PIERWSZA FALA
}

\author{
Emigracja jest to rodzaj pogrzebu, po którym życie trwa dalej. \\ Tadeusz Kotarbiński ${ }^{1}$
}

Migracja jest ogólnoświatowym zjawiskiem, które występuje od czasu powstania pierwszych skupisk ludzkich osiedlających się na danym terenie. Obejmuje ona wiele aspektów codziennego życia, m.in. ekonomiczny, społeczny czy dotyczący naszego bezpieczeństwa ${ }^{2}$. Słowo migracja wywodzi się z łacińskiego migratio, które oznacza przesiedlenie; w myśl definicji z Encyklopedii PWN rozumie się ją jako ,przemieszczenia terytorialne związane ze względnie trwałą zmianą miejsca zamieszkania"3. Stany Zjednoczone, tygiel narodów (melting pot), powstały głównie właśnie dzięki setkom tysięcy obywateli innych państw, którzy, aby rozpoczać nowe życie w lepszym miejscu, zdecydowali się na migrację. W $^{4}$ ten sam sposób, wraz z początkiem ,goracczki złota”, dotarli tam również mieszkańcy Chin, w których świadomości Ameryka kreowała się jako „Złota Góra” (the Gold Mountain), miejsce, gdzie chińscy imigranci będą mogli spełniać swój amerykański sen (American Dream). Niestety, regulacje prawne (exclusion acts) wstrzymały migrację obywateli Chin do USA oraz odmawiały obywatelstwa tym Chińczykom, którzy już zamieszkiwali w Stanach Zjednoczonych. Mimo że przez ponad sześć dekad (1882-1943) obywatele Państwa Środka nie byli pożądani na amerykańskiej ziemi, nie zniechęcało ich to do bardzo niebezpiecznej, nielegalnej emigracji. Chociaż naukowcy wciąż prowadzą dyskurs, czy Chińczycy przypłynęli do Ameryki przed Krzysztofem Kolumbem, to pierwsze potwierdzone dane o obywatelach chińskich zamieszkujących Stany Zjednoczone pochodzą ze spisu ludności z roku 1830 i wymieniaja trzy osoby tego pochodzenia zamieszkujące USA. Trzeba zauważyć, że kwestionariusze spisu ludności nie posiadały wtedy jeszcze wyodrębnionej rubryki dotyczącej rasy i przynależności etnicznej, dlatego nie

\footnotetext{
1 M. Kita, E. Polański, Stownik paronimón cayli wyrazów mylonych, Warszawa 2004, s. 71.

2 World Migration Report 2018, International Organization for Migration 2017, s. 1.

3 https://encyklopedia.pwn.pl/haslo/migracje;3941121.html (dostęp: 5.05.2018).

4 S.M. Mahfouz, America's Melting Pot or the Salad Bowl: The Stage Immigrant's Dilemma, „Journal of Foreign Languages, Cultures \& Civilizations" 2013, vol. 1, no. 2, http://jflcc.com/journals/ jflcc/Vol_1_No_2_December_2013/1.pdf (dostęp: 5.05.2018).
} 
można sprawdzić, czy była to rzeczywista liczba obywateli Chin zamieszkujących Stany Zjednoczone $e^{5}$.

Migrację obywateli Państwa Środka do Ameryki można podzielić na trzy okresy, tzw. fale. Ze względu na ograniczoną objętość artykułu przedstawiam ogólną charakterystykę wszystkich trzech fal, a szczegółowo omawiam wyłącznie pierwsza. Kolejne zostaną opisane w osobnych artykułach. Pierwsza fala imigracji nastąpiła po odkryciu złóż złota w Kalifornii w 1848 r. i wybuchu ,gorączki złota” (the Gold $R u s h)^{6}$. Zaledwie dwie dekady później, według danych pochodzących ze spisu ludności z 1860 r., łączna liczba mieszkańców USA pochodzenia chińskiego wynosiła już 34 9337. Niestety, „Złota Góra” szybko straciła swój blask, a Chińczycy, którzy przybyli do Stanów Zjednoczonych, aby się wzbogacić, musieli znaleźć inny sposób na zapewnienie sobie dobrobytu. Część z nich została zatrudniona jako robotnicy przez Central Pacific Railroad Company, firmę budującą transkontynentalną linię kolejowa, reszta natomiast znalazła zatrudnienie w restauracjach, na farmach, otworzyła swoje własne sklepiki bądź pralnie ${ }^{8}$.

W latach 70. XIX w., kiedy wybudowano już Pierwszą Kolej Transkontynentalna (First Transcontinental Railroad) i brakowało miejsc pracy, a w związku z tym poziom bezrobocia znacząco wzrósł, biała część społeczeństwa Kalifornii sprzeciwiała się przyjmowaniu imigrantów z Azji, którzy stanowili dużo tańszą siłę roboczą niż mieszkańcy zachodniego wybrzeża USA. Dodatkowo większość Chińczyków nie planowała pozostać w Stanach Zjednoczonych na stałe. Migrowali głównie po to, aby wzbogacić się w Ameryce i po kilku latach wrócić do swojej rodziny, która zostawili w Chinach. W związku z tym nie asymilowali się ze społeczeństwem amerykańskim, co tym bardziej pogłębiało barierę między przybyszami z Państwa Środka a mieszkańcami USA?.

Apogeum napięć na tle rasowym zaowocowało wprowadzeniem w 1882 r. aktu prawnego zabraniającego migracji robotników z Chin przez okres 10 lat oraz uniemożliwiającego Chińczykom już zamieszkującym Stany Zjednoczone ubieganie się o obywatelstwo amerykańskie (Chinese Exclusion $A c t^{10}$ ). Jednakże dokument ten dotyczył tylko robotników, a więc osób mniej pożądanych w USA, nie zabraniał natomiast przesiedlania się kupców, nauczycieli, studentów czy osób o wyższym statusie społecznym, których przybycie wpływałoby korzystnie na rozwój Stanów Zjednoczonych. Wprowadzenie tego aktu było początkiem drugiej fali w historii migracji obywateli Chin do Ameryki. Wielokrotne tworzenie kolejnych aktów prawnych

5 Zhao Xiaojian, Asian American chronology: Chronologies of the American mosaic, Santa Barbara 2009, s. 6; „Population Bulletin: America's Racial and Ethnic Minorities” 1999, vol. 54, no. 3, s. 8-9.

6 J. Pfaelzer, Driven out: The Forgotten War against Chinese Americans, New York 2008, s. 2.

7 J. Yung, Unbound feet: A social history of Chinese women in San Francisco, Berkeley 1995, s. 293.

8 J. Pfaelzer, Driven out..., s. 45.

9 Ibidem, s. 10.

10 Federalny akt prawny podpisany 6 maja 1882 r. przez prezydenta Chestera A. Arthura. 
mających na celu uniemożliwienie napływu robotników z Państwa Środka do USA sprawiło, że początkowe ich dziesięcioletnie wykluczenie rozciągnęło się w czasie na ponad 60 lat, począwszy od 1882 do 1943 r. ${ }^{11}$ Po wprowadzeniu pierwszego z wielu aktów zabraniających migracji robotników z Chin liczba obywateli chińskich w USA spadła z 107488 osób w 1890 r. do 61639 w 1920 r.

W 1924 r. wprowadzono jeszcze bardziej rygorystyczne prawo dotyczące imigracji, Immigration Act of $1924^{12}$. Spowodowało ono również, że ci wybrani, którzy mogli ubiegać się o wpuszczenie na teren USA, a więc osoby o wyższym statusie społecznym, najpierw musieli przechodzić bardzo szczegółowe inspekcje na Angel Island, wyspie znajdującej się u wybrzeży Kalifornii, gdzie utworzono centrum imigracyjne dla przybyszy z Azji. Podczas II wojny światowej, kiedy Chiny wsparly Stany Zjednoczone w sojuszu przeciwko Japonii, Amerykański Kongres przyjął Magnuson Act of $1943^{13}$, który znosił poprzednie restrykcje dotyczące chińskich klas społecznych mogących ubiegać się o przyjęcie w Stanach Zjednoczonych. Prawo to nie zniwelowało do końca ograniczeń związanych z imigracja mieszkańców Chin. Nadal obowiązywał Immigration Act of 1924, który limitował napływ imigrantów do 2\% liczby obywateli danego kraju zamieszkujących Stany Zjednoczone według danych spisu ludności z lat 1890 i 1920, czyli z okresu, kiedy Chińczycy byli wykluczeni z możliwości imigracji do USA. W związku z tym roczny limit dla obywateli Chin wynosił jedynie 105 osób $^{14}$. W następnych latach kolejne akty prawne przyznawały dodatkowe przywileje przybyszom z Chin, aż do 3 października 1965, kiedy prezydent Lyndon B. Johnson podpisał Immigration and Nationality Act of 1965, liberalizujący zasady polityki imigracyjnej oraz ustalający stały limit kwotowy na poziomie 20 tysięcy imigrantów rocznie z każdego kraju świata. Rozpoczęło to napływ obywateli chińskich do Stanów Zjednoczonych $i$ ten trend utrzymuje się do dnia dzisiejszego. Zgodnie z danymi Amerykańskiego spisu ludności z 2010 r. aż 4010114 osób zamieszkujących USA przyznało się do chińskiego pochodzenia ${ }^{15}$.

Pierwsi Chińczycy przybywający do Stanów Zjednoczonych przypływali w pojedynkę lub w małych grupach. Zmieniło się to, gdy 24 stycznia 1848 r. James W. Marshall odkrył złoża złota w Colomie w Kalifornii, co wywołało „gorączkę złota". Chińczycy pochodzący z miast znajdujących się na wybrzeżu, m.in. z Szanghaju, Kantonu i Hongkongu, które były zaangażowane w międzynarodowy handel morski, szybko dowiedzieli się o tym odkryciu. Informacja o możliwości

11 E. Lee, At America's Gate: Chinese Immigration during the Exclusion Era, 1882-1943, Chapel Hill - London 2003, s. 43-45.

12 Federalny akt prawny podpisany 24 maja 1924 r. przez prezydenta Calvina Coolidge'a.

13 Federalny akt prawny podpisany 17 grudnia 1943 r. przez prezydenta Franklina D. Roosevelta.

14 E. Lee, At America's Gate..., s. 45-46, 91, 245.

15 J. Yung, Unbound Feet..., s. 293; E. Lee, At America's Gate..., s. 247; https://www.census.gov/ prod/cen2010/briefs/c2010br-11.pdf (dostęp: 15.03.2018). 
wzbogacenia się obiegła cały kraj jeszcze przed pierwszymi doniesieniami prasowymi; kapitanowie statków zmieniali ich kursy, aby wyruszyć do Kalifornii, niektórzy nawet porzucali ładunek, jaki mieli z sobą, aby jak najszybciej móc dostać się w rejon pasma górskiego Sierra Nevada. Chińczycy, często żyjący w ubóstwie, sprzedawali cały swój dobytek oraz zapożyczali się, żeby móc udać się w podróż do „Złotej Góry”"

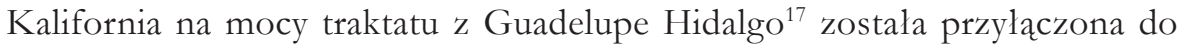
Stanów Zjednoczonych w 1848 r., w związku z czym na początku trwania ,gorączki złota" region ten był jeszcze pozbawiony praw wewnętrznych, władz czy nawet określonych granic ${ }^{18}$. Chińczycy przybywający z kraju, w którym tradycja i zasady miały duże znaczenie $\mathrm{w}$ życiu codziennym, mieli problem $\mathrm{z}$ odnalezieniem się w tym pozbawionym reguł świecie. Dodatkową bolączką był fakt, że w chińskim społeczeństwie to kobiety odpowiadały za kultywowanie tradycji, a do Stanów Zjednoczonych przybywali głównie mężczyźni, którzy albo byli samotni, albo zostawiali swoje rodziny w Chinach. W 1860 r. liczba kobiet chińskiego pochodzenia w Ameryce wynosiła tylko 5\% całej populacji Chińczyków zamieszkujących Stany Zjednoczone. Dodatkowo większość z tych kobiet nie przypłynęła do Kalifornii z własnej woli, były porywane z miast portowych w Chinach i transportowane przez Pacyfik, aby świadczyć usługi seksualne w Ameryce. Brak kobiet w chińskich społecznościach w USA powodował, że Chińczycy byli traktowani jako obcy, którzy, gdy tylko się wzbogaca, wrócą do swoich rodzin w Chinach. Prawo stanowe Kalifornii zabraniało małżeństw międzyrasowych między osobami pochodzenia chińskiego a białą częścią społeczeństwa, aby utrudnić proces asymilacji Chińczyków w Stanach Zjednoczonych. Nie powstrzymywało to jednak białych mężczyzn od wykorzystywania chińskich kobiet zmuszanych do prostytucji ${ }^{19}$.

W ciagu 2 lat od momentu odkrycia złóż złota do Kalifornii przybyli nie tylko Chińczycy, lecz także obywatele Europy: Irlandczycy, którzy uciekali przed wielkim głodem $^{20}$, Francuzi, Polacy czy Niemcy, zmuszeni do opuszczenia swoich ojczyzn po powstaniach i rewolucjach, jakie przetoczyły się przez ich kraje. Ich głównym celem nie była migracja zarobkowa, lecz pragnienie znalezienia miejsca, w którym można rozpocząć nowe życie. Jednak zwiększony napływ ludności do Kalifornii spowodował, że dotychczasowi mieszkańcy tego stanu poczuli się zagrożeni. Głównym problemem był fakt, że imigranci stanowili „tanią siłę roboczą” i byli chętniej zatrudniani przez pracodawców. Przybysze z Azji byli łatwiejsi do rozpoznania ze

16 J. Pfaelzer, Driven out..., s. 3-5.

17 Traktat pokojowy podpisany 2 lutego 1848 r. w Guadelupe Hidalgo (Meksyk), kończący wojnę amerykańsko-meksykańską.

18 J. Pfaelzer, Driven out..., s. 5.

19 J. Yung, Unbound feet..., s. 293; J. Pfaelzer, Driven out..., s. 5-10.

20 Ang. Great Hunger, lata 1845-1849, kiedy masowa choroba ziemniaków zniszczyła zbiory. 
względu na swój odmienny wygląd oraz pochodzenie z innego kręgu kulturowego, często trudnego do zaakceptowania dla białych mieszkańców zachodniego wybrzeża, dlatego głównie na nich skupiły się ruchy antyimigracyjne.

Pierwsze demonstracje przeciwko Chińczykom wybuchły już w 1849 r., a hasło „Kalifornia dla Amerykanów!” rozprzestrzeniało się po terenie Sierra Nevada i całej Kalifornii. W zależności od miejsca, w którym aktualnie przebywali, chińscy wydobywcy złota zostali zmuszeni do opuszczenia swoich obszarów wydobycia w ciagu 24 godzin lub do niesasiadowania z obszarami zajmowanymi przez białych mieszkańców. Po brutalnym ataku białych wydobywców na Chińczyków w Salvado imigranci z Chin postanowili przenieść się do Tuolumne County, gdzie powstała najprawdopodobniej pierwsza osada zamieszkała tylko przez Chińczyków.

Mimo coraz większej liczby ataków na imigrantów z Chin nie zniechęcało to kolejnych przybyszy do starania się o lepsza przyszłość w Ameryce. Jednakże pragnienie pozbycia się z Kalifornii nie tylko Chińczyków, ale też obywateli Polinezji czy nawet Południowej Ameryki było coraz silniejsze. W 1852 r. poszczególne hrabstwa zaczęły wprowadzać najrozmaitsze prawa, które miały na celu zniechęcenie zwłaszcza imigrantów z Azji do pozostania w Ameryce oraz przejęcie ich ziem. W rezultacie Chińczycy nie mogli posiadać ziemi, nie mogli pracować przy wydobyciu złota, nie wspominając nawet o byciu zatrudnianym przez białych. $Z$ roku na rok sytuacja się pogarszała i mimo że w 1853 r. w samym Shasta County były ponad 3 tysiące chińskich mężczyzn pracujących przy wydobyciu złota, do końca 1860 r. zostało z nich tylko 160 osób, z czego około 100 było nadal zaangażowanych w przemysł górniczy ${ }^{21}$.

Chińczycy przypływający do Stanów Zjednoczonych byli wolnymi ludźmi, zarówno w ich mniemaniu, jak i w świetle konstytucji Kalifornii, która zabraniała niewolnictwa. W związku z tym chińscy robotnicy mogli dowolnie zmieniać pracę. Jednakże wielu z nich zaciagało duże pożyczki, aby pokryć koszty podróży przez Pacyfik, zadłużało się u firm przewozowych, u pośredników oferujących pracę, a nawet u kupców będących już na miejscu w Stanach Zjednoczonych, a wszyscy oni czerpali zyski z tych długów i odsetek, później zaś z pracy swoich dłużników. Mimo że Chińczycy przypływali z własnej woli, teoretycznie jako wolni ludzie, często wykonywali pracę służebną (ang. intendured servitude) na podstawie kontraktów podpisywanych przed wypłynięciem ze swojej ojczyzny, a które odpracowywali w Ameryce nawet przez okres 7 lat. W zwiazku z tym w stosunku do zadłużonych pracowników zaczęto używać pejoratywnego określenia „kulisi” (ang. coolies) ${ }^{22}$, wywodzącego się z języka chińskiego i składającego się z dwóch znaków: kŭ (苦) - znaczącego cierpienie lub trudności oraz lì (力) - oznaczającego siłę. Wysokie zyski osób zaangażowanych w sprowadzanie Chińczyków do Ameryki spowodowały

${ }^{21}$ J. Pfaelzer, Driven out..., s. 5-16.

22 https://sjp.pwn.pl/sjp/kulis;2476394 (dostęp: 13.03.2018). 
wytworzenie się swego rodzaju chińskiej elity w Kalifornii23. ${ }^{23}$ Na wzór zaczerpnięty ze swojej ojczyzny Chińczycy utworzyli tzw. stowarzyszenia, które zrzeszały osoby pochodzące z tych samych miast czy prowincji w Chinach ${ }^{24}$. Ich głównym celem było wsparcie oraz ochrona ekonomiczna osób znajdujących się w podobnej sytuacji, czyli imigrantów na amerykańskiej ziemi ${ }^{25}$.

Po odkryciu złota w Kalifornii San Francisco stało się swoistym centrum życia Chińczyków w tym stanie. Już w 1850 r. pojawiły się pierwsze wzmianki o organizacjach jednoczących obywateli Chin na emigracji, jednakże nie miały one jeszcze konkretnej nazwy. Kiedy w latach 50. XIX w. coraz więcej Chińczyków przypływało do Stanów Zjednoczonych, mieli oni tendencję do tworzenia wspólnot z osobami posługującymi się tymi samymi lub podobnymi dialektami, pochodzącymi $\mathrm{z}$ tych samych prowincji. Liderami takich grup byli kupcy jako bardziej zamożni oraz wykształceni. Stowarzyszenia te były nazywane z języka chińskiego buiguăn (会馆), a w języku angielskim companies. Dwa pierwsze oficjalne buiguan zostały powołane w 1851 r. w San Francisco, aż w końcu powstało sześć takich stowarzyszeń, znanych pod nazwa Chinese Six Companies. Do roku 1855 prawie 40 tysięcy imigrantów z Państwa Środka skorzystało z pomocy i usług oferowanych przez buiguan, zarówno przy organizacji przeprawy przez ocean, później przy poszukiwaniu pracy w Ameryce, jak i w sytuacji problemów zdrowotnych. Stowarzyszenia te służyły też do ogólnego trzymania dyscypliny wśród imigrantów. Skorzystanie z tej pomocy oznaczało dużo łatwiejsze dostanie się do Stanów Zjednoczonych i gwarantowało szybkie znalezienie pracy, jednak wiązało się z zaciaganiem wysokiej pożyczki, w związku z czym Chińczycy przyjeżdżający do Ameryki nie mogli wzbogacać się tak szybko, jak to sobie wyobrażali. W porozumieniu z przewoźnikami Chinese Six Companies wydawały dokumenty umożliwiające opuszczenie terenu Stanów Zjednoczonych i powrót do ojczyzny, jednakże było to możliwe tylko wówczas, gdy została potwierdzona spłata zaciagniętego długu. Stowarzyszenia te działały również na rzecz swoich rodaków w Kalifornii, reprezentowały chińską społeczność przed władzami stanowymi, dzięki czemu chińscy imigranci byli traktowani lepiej niż Afroamerykanie czy rdzenni Amerykanie. Niestety, nie dotyczyło to wszystkich praw ${ }^{26}$.

Wśród białej części społeczeństwa rozprzestrzeniał się mit, że wszyscy Chińczycy to kulisi, czyli ktoś pomiędzy wolnym człowiekiem a niewolnikiem. Miało to uzasadnienie w tym, że rząd Stanów Zjednoczonych aktywnie nie protestował przeciwko sprowadzaniu obywateli chińskich jako niewolników, mimo że

23 J. Pfaelzer, Driven out..., s. 25-27.

24 https://www.britannica.com/topic/huiguan (dostęp: 13.03.2018).

25 Him Mark Lai, Becoming Chinese American: A bistory of communities and institutions, New York 2004, s. 40.

26 Ibidem, s. 39-42; J. Pfaelzer, Driven out ..., s. 25. 
w 1807 r. Kongres na mocy Act Probibiting Importation of Slaves ${ }^{27}$ zakazal przywozu niewolników na teren Ameryki. W 1808 r., kiedy ustawa ta zaczęła obowiązywać, Kalifornia nie była jeszcze terytorium USA, jednakże po podpisaniu traktatu z Guadelupe Hidalgo w 1848 r. również na terenie tego stanu wprowadzone zostały przepisy federalne. Pośrednicy w chińskich portach porywali zarówno kobiety, sprzedawane później jako prostytutki, jak i mężczyzn wykorzystywanych na plantacjach trzciny cukrowej na Kubie lub przy wydobyciu guano w Peru. Statki, którymi byli transportowani chińscy niewolnicy, pływały pod amerykańską banderą i były budowane na wzór statków przywożących pierwszych afrykańskich niewolników do Ameryki.

Dnia 19 lutego 1862 r. amerykański Kongres podpisał Prohibition of Coolie Trade Act (Akt zakazujący handlu chińskimi niewolnikami), zainicjowany przez ustawodawców z Kalifornii, który zabraniał amerykańskim statkom przekazywania chińskich niewolników do jakiegokolwiek portu, nawet poza granicami USA. Głównym celem jednakże było złagodzenie rosnącej agresji ze strony białych mieszkańców Kalifornii, którzy uważali, że chińscy imigranci są ich głównym rywalem na rynku pracy, gdyż zadowalają się niższa pensją. Mimo że prawo federalne nie zabraniało imigracji Chińczyków i traktowało ich jako pełnoprawnych mieszkańców Stanów Zjednoczonych, to legislacja stanu Kalifornia stopniowo przekształcała ich w świetle prawa w „rasę czarna”, nadal pozbawiona praw. Chińczycy byli pozbawieni m.in. prawa do głosowania czy zasiadania w ławie przysięgłych. Zabronione również były małżeństwa międzyrasowe. Wszystkie grupy imigrantów, oprócz Chińczyków, mogły ubiegać się o przyznanie im obywatelstwa amerykańskiego, co skrupulatnie wykorzystywano przy tworzeniu następnych dyskryminujących praw. W 1855 r. w Kalifornii wprowadzono prawo, stanowiące, że każdy mieszkaniec stanu, który nie może uzyskać obywatelstwa, musi płacić grzywnę w wysokości 50 USD. Natomiast w 1858 r. ustawodawcy kalifornijscy powołali się na swoje konstytucyjne prawo do wykluczenia grupy społecznej pochodzenia obcego, która w ich odczuciu zagraża interesowi mieszkańców Kalifornii. Liczyli, że statek Frowning Bird, który przypłynął 28 września 1858 r., będzie ostatnim transportem Chińczyków do Stanów Zjednoczonych i że od tej pory liczba obywateli Państwa Środka w Ameryce będzie się zmniejszać. Jednak kuszeni możliwością wzbogacenia się Chińczycy nadal przypływali do USA ${ }^{28}$.

Sąd Najwyższy Stanów Zjednoczonych zaczął popierać ustawy, które nie tylko nie zabraniały dyskryminacji imigrantów z Chin, ale wręcz dawały ciche przyzwolenie na podjęcie kroków zmierzających do pozbycia się „obcych” z amerykańskich ziem. W 1862 r. ustawodawcy kalifornijscy przyjęli Anti-Coolie Act, który zobowiązywał Chińczyków poszukujących pracy na terenie Kalifornii do płacenia

27 Akt federalny podpisany 2 marca 1807 r. przez prezydenta Thomasa Jeffersona.

28 J. Pfaelzer, Driven out..., s. 25-30. 
comiesięcznego podatku. Miało ich to zniechęcać do pozostania w tym stanie, a co za tym idzie - zwiększyć liczbę miejsc pracy dla białych robotników. Sąd niższej instancji uznał ten akt za niekonstytucyjny, jednak Sąd Najwyższy Stanów Zjednoczonych poparł Kalifornię w jej chęci do przyjmowania praw mających na celu pozbycie się Chińczyków z terenu stanu.

Wprowadzono specjalne podatki tylko dla imigrantów, często też wyłącznie nacji chińskiej. Każda osoba pochodzenia chińskiego, która ukończyła 18 lat, a nie zajmowała się wydobyciem złota, produkcją herbaty, kawy, cukru albo ryżu, musiała płacić miesięczny podatek. Prawo to było absurdalne, ponieważ oprócz kawy żadnej z wymienionych upraw nie prowadzono w Kalifornii. W 1882 r. został wprowadzony kolejny podatek Foreign Miners' Tax dotyczący jedynie wydobywców złota obcego pochodzenia. Każdy obcokrajowiec chcący pracować przy wydobyciu złota musiał płacić co miesiąc podatek w wysokości 3 USD. Dopiero po uiszczeniu tej opłaty uzyskiwało się prawo do pracy. W niespełna 3 lata od jego wprowadzenia kwota podatku urosła do 6 USD miesięcznie, a następnie wzrastała o 2 USD rocznie. Ostatecznie kwota ta nie miała już określonego limitu, ponieważ połowa sumy zebranej od wydobywców trafiała do skarbca danego hrabstwa, a druga połowa należała do stanu Kalifornia. Poborcy podatku również chcieli zarobić na tym procederze, więc doliczali jeszcze swoją prowizję. Foreign Miners' Tax obowiązywał w latach 1852-1870 i przez ten czas zmusił Chińczyków do zapłaty kwoty ponad 58 mln USD. Mimo konieczności płacenia wysokich podatków ponad 80\% Chińczyków zamieszkujących Kalifornię nadal było zaangażowanych w wydobycie złota ${ }^{29}$.

Podobne regulacje prawne przyjmowano również w innych państwach, które zmagały się z tzw. żółtym zagrożeniem (yellow peril). Określenie to powstało w drugiej połowie XIX w. i przejawiało się strachem przed migrującymi w poszukiwaniu pracy Chińczykami i Japończykami. Strach ten był napędzany przez łatwo zauważalną odmienność fizyczną Azjatów, rasizm oraz kulturową i religijną inność. Obawiano się, że migranci z Chin i Japonii sprzymierzą się przeciwko krajom Zachodu. Zarówno Amerykanie, jak i Kanadyjczycy czy Australijczycy wprowadzali podatki, które dotyczyły danych grup społecznych wyłącznie na podstawie ich pochodzenia. Często była to po prostu opłata za możliwość przebywania na terenie kraju. Z punktu widzenia obecnej terminologii prawnej nie można by nazwać tej opłaty podatkiem, gdyż ten jest pobierany bez konkretnego świadczenia wzajemnego na potrzeby realizacji działań publicznych. W 1885 r. rząd kanadyjski wprowadził Chinese Immigration Act, w ramach którego zobowiązano każdą osobę pochodzenia chińskiego do zapłaty tzw. Chinese Canadian Head Tax, czyli podatku w kwocie 50 USD za możliwość przekroczenia granicy Kanady. Tak jak w przypadku wspomnianego wcześniej Foreign Miners' Tax, również wysokość

29 Ibidem, s. 30-43. 
Chinese Canadian Head Tax wzrastała kilkakrotnie podczas swojego obowiązywania w latach 1885-1923. W obu krajach opłata ta była stosowana jako środek zniechęcający do imigracji, a nie jako łatwa możliwość wzbogacenia się państwa kosztem migrujących Chińczyków ${ }^{30}$.

Okres zakończenia wojny secesyjnej zbiegł się z zakończeniem kalifornijskiej gorączki złota, w związku z czym Chińczycy pracujący przy jego wydobyciu musieli znaleźć dla siebie inną drogę zarobku. Kalifornia z ekonomicznego punktu widzenia zaczęła rozkwitać, a imigranci z Chin byli zatrudniani przy budowie dróg, systemów nawadniających, w przemyśle wytwórczym oraz zaczęli otwierać własne przedsiębiorstwa: fabryki konserw, zakłady produkujące cygara czy jutę. Zaangażowali się również w rolnictwo, inwestując w zakup winnic i sadów. Mniej zamożni Chińczycy pracowali w sklepach, pralniach lub restauracjach tylko po to, aby spłacić długi zaciągnięte na swoją podróż do Stanów Zjednoczonych. Ci bardziej przywiązani do wydobycia złota wykupili od białych wydobywców wypłukane już ze złota złoża i inwestowali w nowe metody wydobycia, dzięki czemu byli w stanie wydobywać tygodniowo złoto warte nawet 1,5 tysiąca USD. Najbardziej przedsiębiorczy z nich utworzyli swoje kopalnie złota, z których każda zatrudniała ponad setkę robotników. Jednakże ta pozorna stabilizacja chińskiego społeczeństwa w Kalifornii trwała tylko do 10 maja 1869 r., kiedy to ukończono budowę kolei transkontynentalnej i zwolniono wszystkich Chińczyków zatrudnionych w Central Pacific Railroad ${ }^{31}$.

Okres rekonstrukcji USA (ang. reconstruction), czyli odbudowy państwa po wojnie secesyjnej w latach 1865-1877, przyniósł z soba prawa poprawiające sytuację Chińczyków zamieszkujących Stany Zjednoczone. Trzeba jednak zauważyć, że zostały one przyjęte, aby wzmocnić pozycję wyzwolonych niewolników, a nie obywateli Państwa Środka. Przepisy zawarte w Civil Rights Act z 1866 r. zostały rozszerzone w Enforcement Act z 1870 i 1871 r. oraz w Ku Klux Klan Act z 1871 r. i dotyczyły wszystkich ludzi na obszarze Stanów Zjednoczonych, wyłączając jednak z tego nieopodatkowanych Indian. Rozporządzenia te pozwalały zawierać umowy, pozywać, być stroną lub świadkiem w sądzie czy zarządzać swoim dobytkiem. Wszyscy mieszkańcy Ameryki mieli czerpać takie same korzyści i przywileje, niezależnie od koloru skóry. Niestety, prawo federalne nie było respektowane na wschodzie - w Kalifornii Chińczycy nadal byli pozbawieni możliwości ubiegania się o obywatelstwo oraz nie mogli zeznawać przeciwko białym w sądzie. Bezrobotni wydobywcy i zwolnieni z budowy kolei robotnicy zaangażowali się w system

30 P. Napierała, Chiny i Japonia a Zachód. Historia nieporozumien, Kraków 2015, s. 194-207; T. Snarski, Chinese Canadian Head Tax. Prawne mò̇liwości naprawienia niegodziwej przeszłości [w:] Chiny w oczach Polaków. Ksiega jubileuszowa z okazji 60-lecia nawiqzania stosunków dyplomatycznych miedsy Polska a Chińskeq Republika Ludowa, red. J. Włodarski, K. Zeidler, M. Burdelski, Gdańsk 2010, s. 525-529.

31 J. Pfaelzer, Driven out..., s. 45-46. 
połownictwa (sharecropping), polegający na dzierżawieniu ziemi i oddawaniu części zbiorów do właściciela ${ }^{32}$.

W 1868 r. w Waszyngtonie podpisano Burlingame-Seward Treaty między Stanami Zjednoczonymi a imperialnymi Chinami dynastii Qing. Gwarantował on możliwość wzajemnej migracji, naturalizację oraz traktowanie chińskich konsulów w amerykańskich portach na tych samych zasadach co konsulów z Wielkiej Brytanii czy Rosji ${ }^{33}$. Traktat ten, podobnie jak 14. poprawka do Konstytucji Stanów Zjednoczonych, miał być gwarantem lepszej sytuacji dla Chińczyków mieszkających w Stanach Zjednoczonych, a przynajmniej gwarantem podniesienia ich społecznego statusu, ponieważ dotychczas byli traktowani jak ludzie rasy czarnej, którzy dopiero zyskali teoretyczną wolność. Jednak prawa stanowe nadal wykluczały obywateli Państwa Środka ze społeczeństwa, na dodatek ogólna niechęć białych mieszkańców do azjatyckich imigrantów oraz stosowana wobec nich agresja pogłębiały dyskryminację. W 1870 r. zarówno republikanie, jak i demokraci zgodzili się przyznać osobom afrykańskiego pochodzenia możliwość ubiegania się o obywatelstwo. Jednak dwa amerykańskie prawa z roku 1875 - Civil Rights Act i Page Act - w dalszym ciagu zabraniały naturalizowania chińskich imigrantów, jak również nie zezwalały na migrację większości chińskich kobiet. Działo się tak rzekomo po to, aby zapobiegać prostytucji, ale w rzeczywistości prawa te uderzały szczególnie w te kobiety, których mężowie już zamieszkiwali na terenie Stanów Zjednoczonych ${ }^{34}$.

W 1879 r. amerykański Kongres uchwalił Fifteen Passenger Bill (ustawę piętnaściorga pasażerów). Był to przepis określający limit osób pochodzenia chińskiego, które mogły znajdować się na statkach przypływających do amerykańskich portów do 15 - nie więcej. Miało to ograniczyć napływ Chińczyków, jednocześnie nie zabraniając go. Ówczesny prezydent Rutherford B. Hayes zawetował tę ustawę, zwracając uwagę na to, że pogwałca ona ustalenia z traktatu Burlingame-Seward. Nie miał on jednak zastrzeżeń co do chęci ograniczenia migracji obywateli Chin do Stanów Zjednoczonych, lecz do sposobu, w jaki próbowano to osiagnąć. W związku z tym zaproponował, aby wprowadzić zmiany do traktatu z $1868 \mathrm{r}$. W $1880 \mathrm{r}$. James B. Angell, były rektor Uniwersytetu Michigan, został wyznaczony do prac nad rewizją traktatu. W czasie, kiedy Stany Zjednoczone przygotowywały się do podpisania nowego traktatu, Chiny zmagały się z problemami polityki, zarówno wewnętrznej, jak i międzynarodowej. Państwo Środka potrzebowało pomocy USA w pozbyciu się Japończyków z Okinawy, dlatego generał Li Hongzhang zgodził się poświęcić dobro chińskich emigrantów na rzecz otrzymania wsparcia ze strony Ameryki. W związku z tym już w listopadzie 1880 r. został podpisany traktat Angell,

\footnotetext{
32 Ibidem, s. 59-60.

33 Jielin Dong, The Rocky Road to liberty: A documented bistory of Chinese immigration and exclusion, Saratoga 2010, s. 152-156.

34 J. Pfaelzer, Driven out..., s. 59-61.
} 
zezwalający Stanom Zjednoczonym na limitowanie, regulowanie oraz na zawieszanie chińskiej migracji do Ameryki, jednak nie zakazywał jej całkowicie ${ }^{35}$.

Podpisanie 17 listopada 1880 r. traktatu Angell było punktem zwrotnym dla prawa imigracyjnego Stanów Zjednoczonych. Ten moment zakończył okres nielimitowanego napływu chińskich imigrantów, ponadto „otworzył drzwi” dla dalszego ograniczania możliwości migracyjnych oraz wprowadzania aktów wykluczających. W 1882 r. Amerykański Kongres uchwalił Chinese Exclusion Act, który zabraniał migracji chińskich robotników, najmniej pożądanej grupy zawodowej, do Stanów Zjednoczonych przez okres 10 lat. Nakładał również na wszystkich obywateli Chin znajdujących się na terenie Ameryki obowiązek noszenia przy sobie certyfikatu potwierdzającego ich status (robotnik, uczony, dyplomata lub kupiec). Było to pierwsze wprowadzone przez Amerykański Kongres prawo imigracyjne zabraniające imigracji, które bazowało na kraju pochodzenia i rasie. Zakończyło ono pierwszą falę imigracji Chińczyków do Stanów Zjednoczonych ${ }^{36}$.

Zaledwie 34 lata od momentu, kiedy pierwsi obywatele Chin przybyli do Stanów Zjednoczonych, część z nich została pozbawiona możliwości migracji do miejsca, w którym zamierzali spełnić swój amerykański sen. Zmagali się z rasizmem i ostracyzmem społecznym, a mimo to pragnienie opuszczenia Chin, aby doznać dobrodziejstw Ameryki, było silniejsze niż krzywdy, które ich czekały za Pacyfikiem. Odmienność zarówno wizualna, jak i kulturowa Chińczyków od mieszkańców USA powodowała, że z trudnością się asymilowali, tworząc pierwsze Chinatown, które obecnie można spotkać w większości metropolii świata. Mimo że pierwsza fala emigracji zakończyła się w 1882 r., obywatele Państwa Środka nadal wszelkimi sposobami próbowali dostać się, nawet nielegalnie, do Stanów Zjednoczonych. Obecnie stanowią największą grupę etniczną pochodzącą z Azji i nieodłączną część Amerykańskiej kultury.

\section{SUMMARY}

\section{THE FIRST WAVE OF CHINESE IMMIGRATION TO THE UNITED STATES OF AMERICA}

The United States of America is a melting pot of cultures. One of the biggest immigration groups in the USA are people of Chinese descent who, according to US Census data, make up more than $1 \%$ of the whole population of America. This article aims at investigating the tempestuous history of the Chinese immigration to the United States. A brief introduction touches upon the three waves of immigration of the Chinese. Each of those waves shaped

35 M. Gold, Forbidden citizens, Chinese exclusion and the US Congress: A legislative history, Alexandria, VA 2012, s. 492-502; J. Pfaelzer, Driven out..., s. 61; Jielin Dong, The Rocky Road..., s. 152-156, 163-166.

36 Jielin Dong, The Rocky Road..., s. 153; J. Pfaelzer, Driven out..., s. 120. 
a different, although culturally and sociologically significant migration profile. The article then leads to a detailed description of the first wave of immigration, since its beginning in 1848, up to 1882, when the US Congress passed the Chinese Exclusion Act, prohibiting the immigration of Chinese laborers to the USA. The first Chinese came to America looking for an easy way to enrich themselves, after gold had been discovered in California. For less than a half a century, the influx of Chinese immigrants had not been disturbed by the American law, but the situation changed in 1882. The migration policy in the United States played an important role in shaping the immigration flow of Chinese people, and it left deep scars on the Chinese diaspora in the USA. 